\title{
Influence of country image on country brand equity: Application to higher education services
}

\begin{abstract}
Purpose: This paper aims to analyze how country image affects the dimensions of country brand equity (i.e. awareness, image, perceived quality and loyalty) in the higher education sector, as well as the interrelationships between these dimensions.

Design/methodology/approach: The hypotheses were tested using quantitative research involving 208 international students who were starting the academic year at a Spanish university. In accordance with the characteristics of the target population, the subjects interviewed were mainly from Europe and the Americas.

Findings: The results indicate that country image affects the perceived quality and awareness of the universities in the country. Additionally, a hierarchy of effects between the dimensions of country brand equity was found. In particular, loyalty towards the universities of a particular country is positively influenced by their perceived quality, which is affected by the image and awareness of these universities. For its part, the image of universities is positively influenced by the awareness attributed to them by international students.
\end{abstract}

Practical implications: These results have implications for marketing activities aimed at the internationalization of higher education institutions and, therefore, their appeal to international students.

Originality/value: The paper's findings represent an important step in the advancement of knowledge about country brand equity by taking as a basis a complex model that involves the different dimensions of this construct together with a relevant variable in international marketing - country image.

Key words: Country image, country brand equity, awareness, image, perceived quality, loyalty. 


\section{Introduction}

Globalization has resulted in an increasing flow of students and academics across borders within the higher education sector. In this context, countries are increasingly competing in the international education market (Knight, 2011; Wilkins et al., 2012) and universities are developing strategies to become more attractive to international students (Mehtap-Smadi and Hashemipour, 2011). This has led to a notable increase in the number of studies examining the internationalization process in higher education (Huisman, 2013), particularly in terms of understanding students' choice behavior in a global context (Wilkins et al., 2012). In particular, different authors have highlighted the relevance of country characteristics in students' choice of destination for studying abroad (Lee, 2014; Nyaupane et al., 2011; Simpson and Tan, 2009; Srikatanyoo and Gnoth, 2002). In this context, this research aims to examine international students' responses towards universities, taking as a basis the theoretical frameworks related to country image and country brand equity (CBE).

First, the country of origin image (COI), or country image, is used in the literature to refer either to a set of country of origin associations organized into groups in a meaningful way (Kotler et al., 1993), or to all the beliefs that one has about a particular country (Martin and Eroglu, 1993). It is important not to confuse the image of a country with the image of the products from that country (Martin and Eroglu, 1993). In this sense, according to Pappu and Quester (2010) and Pappu et al. (2007), it is possible to distinguish two levels of analysis: the country (macro) and the product (micro) dimensions. The first level refers to all of the beliefs that one has about a particular country, taking into account, for example, economic, political or technological issues (Martin and Eroglu, 1993). This macro image is different from the consumers' attitude towards or associations regarding products or brands from the given country, which conform to the micro country image (Pappu et al., 2007).

The literature on country image has been extensively used to analyze consumers' responses (beliefs, attitudes and intentions) towards foreign products and services (Pharr, 2005). In particular, this theoretical framework has been mainly applied to tangible products, and the evidence available in service sectors is more limited (Roth and Diamantopoulos, 2009; Srikatanyoo and Gnoth, 2002). In the specific field of higher education, works are even scarcer, and Cubillo et al. (2006) and Morris and Lee (2011) highlight the need to continue researching this area. This topic is particularly relevant for the internationalization of higher education services, given that country image has more 
influence when a consumer must evaluate an unfamiliar brand (Lin and Kao, 2004), as is the case for international students at many universities (Cubillo et al., 2006; Srikatanyoo and Gnoth, 2002). Specifically, this study aims to contribute to the academic literature on this topic by examining the role of both the country image and the image of a specific product category from that country (i.e. its higher education services). Whereas the majority of studies focus on either country (macro) or product (micro) image, there is a lack of research about the interrelation of these dimensions (Pappu et al., 2006, 2007; Pappu and Quester, 2010; Zeugner-Roth et al., 2008).

Secondly, the associations regarding the products or brands from a country are one dimension of the country brand equity (CBE) (Zeugner-Roth et al., 2008). The CBE is derived from the brand equity literature (Aaker, 1991, 1996; Keller, 1993; Yoo et al., 2000). This theory has become a valid and useful framework for examining consumers' brand evaluation, preferences and purchase intentions (Christodoulides and de Chernatony, 2010). According to these authors, brand equity is a multidimensional construct. Aaker (1991, 1996) identifies five dimensions: awareness, associations, perceived quality, brand loyalty and other brand assets. Keller (1993) refers to two constructs - awareness and brand image - while Yoo and Donthu (2001) and Yoo et al. (2000) consider the dimensions of brand loyalty, perceived quality and awareness/associations. The brand equity framework has been extensively used in the field of tangible products (Anselmsson et al., 2007; Atilgan et al., 2005; Yoo and Donthu, 2001) and services (Pike et al., 2010; Pike and Bianchi, 2013), and has recently been applied in the field of higher education institutions (Mourad et al., 2011; Sharma et al., 2013).

As stated above, the notion of brand equity has been extended to countries, and researchers have proposed the concepts of country brand equity (Shimp et al., 1993; Zeugner-Roth et al., 2008) and country equity (Pappu and Quester, 2000). According to Zeugner-Roth et al. (2008), country brand equity can be defined as the aggregate brand equity of the products originating from a specific country. Pappu and Quester (2010) consider country equity to be the value endowed by the name of the country on products from that country. Despite its conceptual development, empirical works about its effects and measurement are scarce (Pappu and Quester, 2010; Zeugner-Roth et al., 2008). The different approaches used in past research, as well as the scarcity of works on country brand equity, motivated our paper to advance the knowledge of this topic by studying the CBE in the service field and, specifically, in the category of higher education 
institutions/universities. This work adopts a different perspective compared to previous works (Pappu et al. 2007; Pappu and Quester, 2010; Zeugner-Roth et al., 2008) in the sense that it analyzes the relationships or chain of effects existing between the dimensions of country brand equity (awareness, perceived quality, associations and loyalty) for the service category under investigation, and the potential influence of country image on them. To the best of the authors' knowledge, no study currently exists that has tested these relationships empirically.

With this in mind, this research provides three main contributions to the academic literature. First, it develops an integrative model that includes the hierarchy of effects and interrelations between the dimensions of country brand equity - an issue on which no research has yet been carried out. Second, it combines the research on country image and country brand equity, providing theoretical and empirical support to a topic little researched to date (Zeugner-Roth et al., 2008). Finally, it obtains empirical evidence in the field of services, and specifically for higher education institutions where these variables have been rarely studied.

\section{Literature review and research hypotheses}

\subsection{Country brand equity: concept, dimensions and previous studies}

Country brand equity (CBE) is an extension of brand equity theory. Brand equity is such a complex concept that it has given rise to many diverse conceptualizations and definitions, both academic and practical. Regarding this issue, and on the basis of an extensive review of the literature, Christodoulides and de Chernatony (2010) identify two major perspectives of study: firm-based brand equity (FBBE), which focuses on the financial value which a brand offers a business (Simon and Sullivan 1993), and the consumer-based perspective, which reflects consumers' response to a brand name, which is based on the consumer perceptions that determine the market share and profitability of such a brand (Aaker, 1991; de Chernatony et al., 2004; Christodoulides et al., 2006; Keller, 1993, 2003; Pappu et al., 2005; Yoo and Donthu, 2001).

The dominant stream of research about consumer-based brand equity is rooted in cognitive psychology (Christodoulides and de Chernatony, 2010), focusing on consumers' perceptions and attitudes. In this vein, Aaker (1991, p.15) defines brand equity as 'a set of assets and liabilities linked to a brand, its name and symbol, which add to or subtract from the value provided by a product or service to a firm and/or that firm's customers'. Keller (1993, p.2) defines consumer-based brand equity as 'the differential 
effect of brand knowledge on consumer response to the marketing of the brand' which is formed 'when the consumer is familiar with the brand and holds some favorable, strong, and unique brand associations in memory'.

According to these definitions, consumer-based brand equity is a function of several factors. Among the diverse conceptual typologies of the dimensions of brand equity (see Christodoulides and de Chernatony, 2010 for an extensive review of the literature), the most frequently used is that proposed by Aaker (1991, 1996). In particular, this author identifies four dimensions of brand equity that represent consumer perceptions and reactions to the brand: brand awareness, brand associations, perceived quality and brand loyalty. Aaker $(1991,1996)$ includes a fifth dimension, the proprietary brand assets, which is linked to patents, trademarks and good relationships with distributors, among other issues. Taking into account the special nature of this last construct, we only consider the four dimensions previously cited.

Aaker (1991, p.61) defines brand awareness as 'the ability of a buyer to recognize or recall that a brand is a member of a certain product category'. Thus, brand awareness reflects both brand recognition and recall (Keller, 1993; Yoo and Donthu, 2001). Brand associations are defined as 'anything linked in memory to a brand', 'a set of [brand] associations, usually in some meaningful way', which form brand image (Aaker, 1991, p.109). Brand associations include brand beliefs and attitudes encompassing the perceived benefits of a given brand (Keller, 1993; Netemeyer et al., 2004). Following Zeithaml (1988), Keller (1993) and Aaker (1996), Netemeyer et al. (2004, p.210) defined perceived quality as 'the customer's judgment of the overall excellence, esteem, or superiority of a brand (with respect to its intended purposes) relative to alternative brand(s)'. It is therefore based on consumers' or users' subjective evaluations of product quality (Yoo and Donthu, 2001). Finally, brand loyalty is defined by Aaker (1991, p.39) as 'the attachment that a customer has to a brand'. For its part, Yoo and Donthu (2001) conceive brand loyalty, in the framework of consumer-based brand equity, as the tendency to be loyal to a brand, which is evidenced by the intention to buy the brand as a primary choice. This proposal of four dimensions is used extensively in the marketing literature (Anselmsson et al., 2007; Atilgan et al., 2005; Pappu et al., 2005; Pike and Bianchi, 2013; Pike et al., 2010). Other works consider awareness and associations in a single dimension (Baldauf et al., 2009; Yoo and Donthu, 2001; Yoo et al., 2000).

The theory of consumer-based brand equity can be applied to countries. Several studies conducted since the work of Shimp et al. (1993) use the concepts of country brand 
equity (CBE) and country equity (CE) above all from a conceptual perspective (Pappu and Quester, 2010). CBE can refer to an overall perception of the products/brands of a country (Zeugner-Roth et al., 2008), while the CE is the value endowed by the name of the country on products from that country (Pappu and Quester, 2010). However, a country can be seen as a corporation that produces many products, so it may enjoy different equity profiles in different product categories (Pappu and Quester, 2010). Consequently, its study can be product category-specific (Thakor and Katsani, 1997).

With regard to its measurement, and taking as a base Aaker's (1991, 1996) proposal, Iversen and Hem (2001) suggest that the CBE is a multi-dimensional construct composed of four dimensions: country (brand) awareness, country (brand) associations, country (brand) perceived quality and country (brand) loyalty. This approach is adopted by Zeugner-Roth et al. (2008), although they combine awareness and associations into a single dimension. Pappu and Quester (2010) consider the CE as a second-order construct composed of the macro country image, micro country image, country awareness, perceived quality and country loyalty (see Table 1).

Specifically, our work studies the country brand equity in the specific category of higher education institutions and the way in which the country image influences the dimensions of CBE. The study assumes a new focus with regard to the previous works. For example, unlike Pappu et al. (2007), this paper introduces the concept of CBE and its dimensions and focuses on a product category rather than specific brands. In relation to Zeugner-Roth et al. (2008), our paper does not analyze CBE as a second-order factor but studies the relationships between all of the dimensions. Additionally, whereas they measure the perceptions of the entire brands of a country, the present research focuses on a specific product category. Pappu and Quester (2010) analyze the measurement of CE and do not propose the chain of effects that our study postulates. Finally, Sharma et al. (2013) only study consumer-based brand equity for a particular higher education institution and not for all of the universities (product category) in a country.

\section{Table 1}

\subsection{Relationships between dimensions of country brand equity}

Most research on consumer-based brand equity focuses on the measurement of brand equity (Atilgan et al., 2005; Christodoulides and de Chernatony, 2010; Yoo and Donthu, 2001). Other works examine the joint effect of brand equity dimensions on 
different result variables, such as consumer preference and purchase intention (Netemeyer et al., 2004; Sharma et al., 2013), brand profitability performance (Baldauf et al., 2009) or consumer price acceptance (Anselmsson et al., 2007), among others. In recent studies, different authors have highlighted the need to research the interrelationships between the different dimensions of consumer-based brand equity (Pike et al., 2010; Pike and Bianchi, 2013), which can also be extended to country brand equity. In this field, the majority of studies adopt a conceptual approach, with few empirical works (Pappu and Quester, 2010; Zeugner-Roth et al., 2008). To the best of the authors' knowledge, there have been no studies of the relationships between the dimensions of CBE. In consequence, we support our hypotheses based on past research on consumerbased brand equity.

In this context, the relationship between perceived quality and consumer loyalty is well established in the marketing literature (Baek and King, 2011; Pike et al., 2010). According to this evidence, the quality perceived by consumers (e.g. international students) regarding the product category/brands of a country (e.g. country's universities) will directly influence the loyalty towards these products in terms of intention to repurchase and willingness to recommend. However, the evidence in the field of consumer-based brand equity of universities is contradictory. Thus, Lin and Tsai (2008) and Nguyen (2009) support the positive influence of perceived quality on loyalty towards a university, but Brown and Mazzarol (2009) and Perin et al. (2012) only find a weak and indirect effect. In light of the evidence provided in the general marketing literature, the following research hypothesis is proposed:

H1. The perceived quality of a country's universities will have a direct and positive influence on loyalty towards its universities.

Abundant literature in the field of consumer behavior supports the effect of the image of a product, service or brand on perceived quality. According to Lee et al. (2011) perceived quality can be influenced by information about intrinsic cues (e.g. brand features) and other extrinsic cues such as brand image. Research has demonstrated the positive relationships between brand image and perceived quality of service or products (Bloemer et al., 1998; Cretu and Brodie, 2007; Hankinson, 2005). Given this previous literature, if potential customers (e.g. international students) perceive a positive image of 
the universities located in a country, they are also likely to perceive a higher quality in those institutions. With this in mind, a second hypothesis is posited:

H2. The image of a country's universities will have a direct and positive influence on the perceived quality of its universities.

Finally, different models of consumer behavior identify awareness as a primary determinant of brand loyalty (Konecnik and Gartner, 2007), and 'the ticket to enter the market' (Pike, 2007, p.53). In general, marketing literature coincides in that brand awareness is an antecedent to brand dominance in the market, increasing the probability of the brand being considered (Mohd et al., 2007). According to the associative network model, memory is formed by nodes which consist of stored information connected by links of different strengths (Anderson, 1983; Keller, 1993). A brand represents a potential node with which a variety of associations are linked (Pike et al., 2010), and brand awareness reflects the strength of the brand node in the minds of consumers. Therefore, it is to be expected that greater awareness of a brand will enhance the associations linked to it, both those that comprise the brand image (Bigné et al., 2013) and perceptions relating to quality (Pike et al., 2010). That is to say, if students consider a country's universities to be known internationally, they will endow them with more positive associations and higher perceived quality. On the basis of this theory and previous works, the following hypotheses in the context of higher education services are proposed:

H3. Awareness of a country's universities will have a direct and positive influence on the image of its universities.

H4. Awareness of a country's universities will have a direct and positive influence on the perceived quality of its universities.

\subsection{Influence of country of origin image on dimensions of country brand equity}

Country of origin image (COI) or country image is defined as the sum of the beliefs, ideas and impressions that people have about a country, and is represented by the simplification of a large number of informational associations and indications connected with a place (Kotler et al., 1993; Kotler and Gertner, 2002; Martin and Eroglu, 1993). According to Pappu et al. (2007) and Pappu and Quester (2010), COI can be measured at 
a macro level, related to all of the beliefs one has about the different aspects of a particular country. In this sense, Martin and Eroglu (1993) consider economic, political or technological issues, whereas Anholt (2006) and Roth and Diamantopoulos (2009) consider economic development, quality of life, culture and heritage, tourism, science and technology or socio-political issues. For its part, and as previously established, the micro level refers to beliefs about the products of the country (Pappu et al., 2007; Pappu and Quester, 2010).

Most research in the field of country image analyzes its influence on the evaluation of specific products or services by consumers (Ahmed et al., 2002; Mohd et al., 2007; Peterson and Jolibert, 1995; Pharr, 2005). Thus, country image includes stereotypes and perceptions about the country that are used by consumers as shortcuts for information processing and consumer decision heuristics (Kotler and Gertner, 2002). Accordingly, country image exerts a 'halo effect', from which consumers infer the attributes of products and services from their perception about its country of origin (Ahmed et al., 2002; Han, 1989). This effect is particularly relevant when the consumer has to evaluate an unfamiliar brand (Lin and Kao, 2004), as is the case on most occasions when students are choosing where to study abroad (Cubillo et al., 2006; Srikatanyoo and Gnoth, 2002).

Peterson and Jolibert (1995) and Pharr (2005) suggest the need to study conative and cognitive effects of country image separately, considering the hierarchical ordering of consumer responses to country of origin. In this regard, consumer-based brand equity is an ideal theoretical framework for studying the influence of country of origin on different consumer responses. Lin and Kao (2004) found that the influence of country of origin operates through brand equity, so the effect of country image on consumer behavior is moderated by brand evaluations. From an extensive review of the literature, Pharr (2005) propounds that country image influences the brand equity of products and services through its influence on brand image and perceived quality. Pappu et al. (2006) show that associations, perceived quality and loyalty towards a brand vary according to the country of origin and the product category. In the same vein, Mohd et al. (2007) obtain empirical evidence that confirms the influence of country image on perceived quality, brand awareness and brand associations in the case of tangible products. In turn, the results obtained by Sanyal and Datta (2011) support the influence of country image on brand awareness and brand equity as a whole. However, the empirical evidence available in the literature does not support in all cases the direct influence of country image on purchase 
intentions (e.g. brand loyalty). Thus, the majority of studies indicate that country image directly influences perceptions of products and brands, which in turn mediates its effects on consumer intentions (Pharr, 2005).

With regard to the specific area of higher education services, only a few papers support the effect of country image separately for the different dimensions of brand equity. Cubillo et al. (2006) and Srikatanyoo and Gnoth (2002) propound that country image positively influences the (brand) image of a higher education institution, which they link directly with perceived quality. Similarly, Mourad et al. (2007) include country of origin as a component of brand image in higher education. More indirectly, as country image is related to economic development, culture and technology (Anholt, 2006; Roth and Diamantopoulos, 2009), this variable could influence the brand awareness perceived by consumers (e.g. international students) of a country's universities. Thus, consumers may perceive that universities in more developed countries are more renowned internationally.

Past research on the influence of country image on brand equity dimensions is practically non-existent in the context of countries. To the authors' knowledge, there are no studies measuring the influence of country image on the dimensions of country brand equity individually. Thus, our paper takes into account the literature on country image, and the evidence available in the field of higher education services, to propose the following hypotheses:

H5. A country's image will have a direct and positive influence on the perceived quality of its universities.

H6. A country's image will have a direct and positive influence on the awareness of its universities.

H7. A country's image will have a direct and positive influence on the image of its universities.

These three hypotheses implicitly reflect the indirect influence of the country image on loyalty towards the country's universities through its effect on the perceived quality, awareness and image of the universities. That is to say, we are proposing implicitly that these three dimensions of CBE have a mediating role in the global effect of a country's 
image on loyalty towards its universities. This is due to the hierarchy of effects between the dimensions of the $\mathrm{CBE}$, which is one of the main theoretical foundations and contributions of this research. Figure 1 summarizes this research hypotheses.

\section{Figure 1}

\section{Methodology}

Quantitative research was carried out to test the above-mentioned hypotheses. Data were collected using a personal questionnaire, which included the following question areas: 1) the dimensions of country brand equity of Spanish universities; 2) Spain's country image; and 3) the sociodemographic characteristics of respondents. The variables of the model were measured using multi-item instruments (10-point Likert scales), which allow us to obtain evaluations of psychological variables that cannot be quantified directly (Churchill and Iacobucci, 2002). A reflective approach was used to measure the variables in the model. Following the framework established by Coltman et al. (2008), this type of measure can be mainly justified by the fact that the items share a common theme for each latent variable, are expected to have high positive intercorrelations, and that variation in the item measures does not cause variation in the latent construct.

The scales were adapted from previous studies in order to ensure content validity (see Appendix 1). The scale for the measurement of country brand loyalty was developed from Anselmsson et al. (2007) and Pike et al. (2010). Country brand awareness and perceived country brand quality were measured through scales based on the works of Pike et al. (2010) and Yoo and Donthu (2001). The scale used to measure country brand image was developed from Anselmsson et al. (2007) and Yoo and Donthu (2001), and adapted to the specific field of higher education services. Finally, the scale used for measuring the country image was adapted from Cubillo et al. (2006), taking as a reference the macro areas proposed by Anholt (2006) and Roth and Diamantopoulos (2009). Although other studies consider these macro areas as different dimensions of the country image with several items for each of them, in our paper only a latent construct of the country image (captured by several items) is considered, in line with Mohd et al. (2007) and Pappu and Quester (2010). This approach, in which each macro area is only measured by one item, is used as the purpose of this study is to estimate the relationships between the country 
image and the other variables included in the research model and not to explore the multidimensional nature of the country image. In this context, in accordance with Bergkvist and Rossiter (2007), the predictive validity of our approach is as valid as the approach involving several multi-item measures.

The target population of the quantitative research was international students starting the academic year at the University of Cantabria (Spain). College students were selected as the reference population because they are the primary present and potential customers of higher education institutions (Brown and Mazzarol, 2009; Cubillo et al., 2006; Mourad et al., 2011). Moreover, student samples are widely used in the research on brand equity (Atilgan et al., 2005; Baek and King, 2011) and country image (Roth and Diamantopoulos, 2009). A convenience sampling procedure was used by distributing the questionnaire to international students brought together in two reception meetings by the International Relations Office. A total of 208 valid responses were obtained (the sociodemographic profile of the sample is summarized in Table 2). The students interviewed were mainly from Europe (55.8\%) and the Americas (34.1\%). The majority were from Germany (14.9\%), Italy (14.9\%), the United States (13.0\%) and Mexico $(12.5 \%)$.

Table 2

\section{Results}

The statistical analyzes were developed using the structural equation modelling (SEM) methodology, using EQS 6.1. First, the measurement model was estimated with confirmatory factor analysis (CFA) to test the psychometric properties of the measurement scales (reliability and validity). Next, the model was estimated in order to contrast the research hypotheses. Finally, and following a well-established approach in SEM (Bagozzi and Yi, 1988; Heslop et al., 2008; Martinez-Lopez et al., 2013), rival models were also estimated to assess the validity of the hypothesized structural model.

Before the results derived from these analyses can be explained, it is necessary to indicate that the Harman's single-factor test was conducted in IBM-SPSS software to check for common method variance (CMV). In other words, a check was made on whether the correlation among variables was significantly influenced or not by their common source (Chang et al., 2010). The results of the analysis indicate that the items 
load into more than one factor, and that they are not concentrated in any one general factor. Consequently, CMV does not significantly influence this quantitative research.

\subsection{Estimation of the measurement model}

The results obtained for the goodness-of-fit indexes show a correct specification for the measurement model. In particular, there are three main classes of fit criteria: measures of absolute fit, measures of incremental fit, and measures of parsimonious fit (Hair et al., 2010). In this case, the statistics adopted are given by EQS 6.1, widely used in the SEM literature (Hair et al., 2010): Bentler-Bonett Normed Fit Index (BBNFI), Bentler-Bonett Non-Normed Fit Index (BBNNFI) and Root Mean Square Error of Approximation (RMSEA) for the measurement of overall model fit; Incremental Fit Index (IFI) and Comparative Fit Index (CFI) as measures of incremental fit; and $\chi^{2}$ and normed $\chi 2$ for the measurement of the parsimony of the model. The results summarized in Table 3 confirm that the BBNFI, BBNNFI, IFI, and CFI statistics exceed or are very close to the recommended minimum value of 0.9. RMSEA is located within the maximum limit of 0.08 , and normed $\chi 2$ takes a value clearly under the recommended value of 3.0 (Hair et al., 2010). Accordingly, although $\chi 2$ shows a p-value of 0.00, the other criteria show a good fit of the measurement model to the data.

\section{Table 3}

The reliability of the measurement scales is evaluated using Cronbach's Alpha, compound reliability and AVE coefficients (Bagozzi and Yi, 1988). The values of these statistics are, in every case, clearly above the required minimum values of 0.7 and 0.5 respectively (Hair et al., 2010), which supports the inner reliability of the proposed constructs (Table 3). The convergent validity of the scales is also confirmed (Table 3), since all items are significant to a confidence level of 95\% and their standardized lambda coefficients are higher than 0.5 (Steenkamp and Van Trijp, 1991).

Discriminant validity of the scales is tested following the procedures proposed by Anderson and Gerbing (1988) and Fornell and Larcker (1981). The approach proposed by Anderson and Gerbing (1988) is a basic test of discriminant validity based on the analysis of confidence intervals for the inter-construct correlations. According to this method, the discriminant validity of the scales used in this research is supported as none of the confidence intervals for the correlation among pairs of factors contains value 1.0. 
The procedure proposed by Fornell and Larcker (1981) is considered a more demanding test of discriminant validity (Grewal et al., 2004), and requires comparison of the variance extracted for each pair of constructs (AVE coefficient) with the squared correlation estimate between these two constructs. If the variances extracted are greater than the squared correlation, this is evidence of discriminant validity. Only one pair of constructs did not pass the test (country image - country brand perceived quality), although the difference between the AVE coefficient and the squared correlations in this case is quite small (Table 4). Given the results for these two procedures, there is reasonable support for the discriminant validity of the scales used in this research.

The correlation matrix and the descriptive statistics of the variables are summarized in Appendix 2.

\section{Table 4}

\subsection{Estimation of hypothesized structural model}

Once the psychometric properties of the scales were adequately examined in the previous stage, the model was estimated using Robust Maximum Likelihood. This method avoids the problems related to non-normality of data by providing the outputs' 'robust chi-square statistic' and 'robust standard errors', which have been corrected for non-normality (Byrne, 1994) and, consequently, guarantee the validity of the model estimation. Figure 2 summarizes the results for the estimation of the proposed research model, indicating the goodness-of-fit indices of the structural model, $\mathrm{R}^{2}$ statistics for each dependent variable, standardized coefficients for each relationship, and the values of the t-student statistic (in parentheses) to test significance.

First, the results obtained confirm that consumers' loyalty towards the country's universities is positively influenced by perceived quality (H1). In turn, the empirical evidence obtained support that the perceived quality of the country's universities is determined by consumers' perceptions about their brand image (H2) and brand awareness (H3), together with country image (H5). Additionally, the results confirm that the brand image of the country's universities is influenced by brand awareness perceived by consumers (H4), but the direct effect of country image on brand image (H6) is not significant. Finally, the empirical evidence obtained confirms the effect of country image on the brand awareness of the country's universities (H7). Therefore, in all cases R-square 
statistics take reasonably high values, which supports the validity of the research model in explaining the variance of the dependent variables studied.

\section{Figure 2}

These findings support the indirect effect of the country image on loyalty towards the country's universities through its direct influence on the perceived quality and awareness of the universities. Additionally, the country image exerts an indirect influence on the brand image of the country's universities through its effect on the brand awareness, which also implies an indirect effect on the brand loyalty. Therefore, a better country image perceived by international students will lead to a higher level of brand awareness and a better perceived quality of the country's universities; this will result in a more positive brand image.

\subsection{Estimation of rival models}

Different authors highlight the importance of competitive modelling in assessing the validity of a hypothesized structural model (Bagozzi and Yi, 1988; Heslop et al., 2008; Martinez-Lopez et al., 2013). Thus, the estimation of rival models allows the comparison of the different models with the aim of selecting the most valid one (Martinez-Lopez et al., 2013). This research considers two alternative theoretical models that have previously been established in the literature on country image and brand equity. These are the rival models proposed by Pappu et al. (2006) and Zeugner-Roth et al. (2008) - two of the scarce pieces of research that study the influence of country image on brand equity.

On the one hand, the model proposed by Pappu et al. (2006) establishes a direct effect of the country of origin on each of the dimensions of brand equity, in this case for a specific brand from the country. Despite these authors not studying CBE but the brand equity of a specific brand, the constructs included in this model are very similar to the ones studied in our research for the case of a country's universities. However, in contrast to our hypothesized model, rival model 1 does not consider any indirect or mediating effects of the country image on the dimensions of CBE, given that Pappu et al. (2006) did not establish any interrelationships between them.

On the other hand, the model proposed by Zeugner-Roth et al. (2008) establishes a direct effect of the country of origin image on country brand equity, considered as a second-order factor formed by the country brand awareness/associations, country brand 
quality and country brand loyalty. Thus, they adopt a global conceptualization of CBE, conceiving it as a single construct with four dimensions, which were measured using a reflective approach. Accordingly, this rival model does not include a direct effect of the country of origin image on the dimensions of CBE or the interrelations between them. Therefore, following Zeugner-Roth et al. (2008), rival model 2 includes the direct effect of the country image on a second-order factor formed by the dimensions of CBE. Specifically, according to the original model proposed and tested by Zeugner-Roth et al. (2008), CBE is measured following a reflective approach.

Table 5 summarizes the goodness-of-fit indices, the Akaike information criterion (Akaike, 1987), and the standardized coefficients of the relationships corresponding to the two rival models analyzed. In the case of rival model 2, the arrows from the CBE to each of its dimensions describe the reflective nature of the second-order factor.

\section{Table 5}

The goodness-of-fit indices for the two rival models considered are similar to or worse than the ones obtained for the hypothesized model. Specifically, in the case of the model based on Pappu et al. (2006), all of the goodness-of-fit indices are worse than those for our model, and its AIC (chi-square adjusted for the number of estimated parameters) is significantly higher than the AIC obtained in our model. Regarding the estimation of the rival model based on Zeugner-Roth et al. (2008), the values obtained for the goodnessof-fit indices and the AIC are very similar to those for our model. However, the model established in this paper makes a clear contribution to the understanding of country brand equity, as it includes the chain of effects between its dimensions and therefore provides better insight into how country brand equity is formed and how it affects consumer behavior (e.g. in terms of loyalty to country brand). Consequently, after two rival models had been tested, no better model was found in the context of the present investigation.

\section{Conclusions}

This paper examines the influence of country image on the dimensions of country brand equity in the higher education sector, taking into consideration the relationships or chain of effects between these dimensions (i.e. awareness, image, perceived quality and loyalty). Given that the country of origin effects may be product category-specific (Pappu and Quester, 2010), the present research focuses on this level. Accordingly, the 
dimensions of country brand equity are measured for a set of higher education institutions in Spain, and brand loyalty is treated as the main outcome variable (Christodoulides and de Chernatony, 2010).

In the first place, the empirical evidence obtained supports the existence of a hierarchy of effects or interrelations between the dimensions of country brand equity. In particular, according to the results, the international students' brand loyalty towards a country's universities is positively influenced by the perceived quality. In turn, the perceived quality of the country's universities is determined by consumers' perceptions about their brand image and brand awareness. Finally, brand image is positively influenced by the brand awareness attributed by consumers (e.g. international students) to the country's universities. Therefore, consumers' intentions to use or recommend the service in the future will be determined by perceived quality, which depends on the image of the country in this service category and consumers' awareness of it. In this sense, consumers will have a better country brand image if they perceive it as recognizable and renowned in the market.

The empirical evidence obtained supports the influence of country image on perceived quality and brand awareness of a country's universities. Thus, consumers' perceptions about the country (in terms of economic development, quality of life, culture and heritage, tourism, science and technology or socio-political issues) will significantly affect their perceptions about the quality and brand awareness of its universities. However, no direct effect of country image on the brand image of the country's universities was found. Thus, country image only exerts an indirect effect on the universities' brand image, through its influence on brand awareness. That is to say, the perceptions about the country determine the consumers' evaluation of the universities' brand awareness, which in turn will affect their beliefs about the brand image.

The findings of this research have important theoretical implications because they represent a relevant step in the advancement of knowledge about CBE. First, to the best of the authors' knowledge, no previous studies have analyzed the interrelationships between the dimensions of country brand equity. In this regard, the present research confirms the existence of a hierarchy of effects between the different dimensions of country equity. Accordingly, the understanding of country brand equity's effect on consumer behavior requires consideration of the interrelations between country brand awareness, image, perceived quality and loyalty. Second, this study confirms the influence of country image on two dimensions of country brand equity (perceived quality 
and brand awareness), providing theoretical and empirical support to a topic little researched to date, and only applied to specific products or brands (Mohd et al., 2007; Pharr, 2005; Sanyal and Datta, 2011). Therefore, this research serves to show how country image influences consumer behavior, affecting consumers' brand loyalty through its influence on brand awareness and perceived quality. Finally, empirical evidence in the field of higher education services is obtained, whereby country image and country brand equity are particularly relevant in students' choice of international institution.

From a managerial perspective, the results have significant implications for marketing activities. The findings are especially important in guiding the international promotion of the universities of a country and, therefore, in attracting international students and generating economic and sociocultural richness for the country. First, managers of higher education institutions should be aware of the interrelations between the dimensions of country brand equity. Specifically, consumers will not be able to evaluate the quality or image of a foreign organization (e.g. university) if they do not know the brand or perceive that its brand awareness (recognition and recall) is low. Therefore, as a first stage, marketing campaigns should place special attention on fostering brand awareness, whereas improving brand image and perceived quality will be more relevant once the brand is recognized and renowned. Finally, only countries with positive brand awareness, brand image and perceived quality in the category of higher education services will be able to maintain high levels of brand loyalty.

Second, universities should define their internationalization strategies based on in-depth analysis of the image projected by the country where the institution is located. Accordingly, public and private managers should identify the strengths that are more relevant for international students in deciding where to study abroad, and highlight these factors as part of the value offer of the institution (Simpson and Tan, 2009; Wilkins et al., 2012). Therefore, communication campaigns designed to attract international students should include a clear and appealing description of the country where the university is located, together with academic and scientific data about the institution. At the same time, internationalization strategies should maintain coherence between the images of the institution and the country. In this sense, some universities (e.g. historical universities in South Europe, such as the University of Bologna or the University of Salamanca) could base their marketing on quality of life or cultural aspects, whereas others could focus on the country's socioeconomic development or technological and scientific competitiveness (e.g. universities in northern Europe or the United States). 
Despite the rigorous methodology used in the empirical research, this study has several limitations. Specifically, the fact that this research focuses on a specific country (Spain) could limit the generalization of the results. It would be very interesting to replicate the study in other countries with different characteristics and images. In any case, Spain should be a good benchmark for the study of the effect of country image on the brand equity of higher education institutions since it is the country that attracts most Erasmus students within the European Union (European Commission, 2014). Furthermore, the sample only involves students who are strongly committed to their university and country of study. This is a limitation of the study, although the surveys were conducted at the very beginning of their stay at their university in order to avoid students' perceptions being influenced by their experiences. Additionally, previous research on the effect of country of origin on consumer behavior has also used samples that include individuals that own or have owned products from the studied countries (Heslop et al., 2008; Pappu et al., 2006; Pappu and Quester, 2010; Zeugner-Roth et al., 2008), and who therefore could be committed to them. Finally, it would be interesting to add new variables to the model such as student satisfaction - a key variable scarcely taken into account in previous studies - or to complete the model by analyzing the influence of country image and country brand equity on a specific university.

\section{References}

Aaker, D.A. (1991). Managing Brand Equity. New York: Free Press.

Aaker, D.A. (1996). Building Strong Brands. New York: Free Press.

Ahmed, Z., Johnson, J., Ling, C., Fang, T., and Hui, A.T.Y (2002). Country-of -origin and brand effects on consumers' evaluations of cruise lines. International Marketing Review, 19(3), 279-302.

Akaike, H. (1987). Factor analysis and AIC. Psychometrika, 52, 317-332.

Anderson, J.C., and Gerbing, D.W. (1988). Structural equation modelling in practice: A review and recommended two-step approach. Psychological Bulletin, 103(3), 411423.

Anderson, J.R. (1983). The Architecture of Cognition. Cambridge: Harvard University Press.

Anholt, S. (2006). The Anholt nation brand index: Special report on Europe's international image, Q2 2006, plus an update on the status of Brand Denmark. Place Branding and Public Diplomacy, 2(3), 263-270. 
Anselmsson, J., Johansson, U., and Persson, N. (2007). Understanding price premium for grocery products: A conceptual model of customer-based brand equity. Journal of Product and Brand Management, 16(6), 401-414.

Atilgan, E., Aksoy, Ş., and Akinci, S. (2005). Determinants of the brand equity. A verification approach in the beverage industry in Turkey. Marketing Intelligence and Planning, 23(3), 237-248.

Baek, T.H., and King, K.W. (2011). Exploring the consequences of brand credibility in services. Journal of Services Marketing, 25(4), 260-272.

Bagozzi, R.P., and Yi, Y. (1988). On the evaluation of structural equation models. Journal of the Academy of Marketing Science, 16(1), 74-94.

Baldauf, A., Cravens, K.S., Diamantopoulos, A., and Zeugner-Roth, K.P. (2009). The impact of product-country image and marketing efforts on retailer-perceived brand equity: An empirical analysis. Journal of Retailing, 85(4), 437-452.

Bergkvist, L., and Rossiter, J.R. (2007). The predictive validity of multiple-item versus single-item measures of the same constructs. Journal of Marketing Research, 44(2), 175-184.

Bigné, E., Andreu, L., and Zanfardini, M. (2013). El Valor de la Responsabilidad Social Corporativa en la Equidad de Marca de Destinos Turísticos. Madrid: Editorial Ramón Areces.

Bloemer, J., De Ruyter, J., and Peeters, P. (1998). Investigating drivers of bank loyalty: The complex relationship between image, service quality and satisfaction. International Journal of Bank Marketing, 16(7). 276-286.

Brown, R.M., and Mazzarol, T.W. (2009). The importance of institutional image to student satisfaction and loyalty within higher education. Higher Education, 58(1), 8195.

Byrne, B.M. (1994). Structural Equation Modelling with EQS and EQS/Windows. Basic Concepts, Applications, and Programming. California: Sage Publications.

Chang, S-J., van Witteloostuijn, A., and Eden, L. (2010). From the editors: Common method variance in international business research. Journal of International Business Studies, 41, 178-184.

Christodoulides, G., and De Chernatony, L. (2010). Consumer-based brand equity conceptualisation and measurement: A literature review. International Journal of Market Research, 52(1), 43-66. 
Christodoulides, G., De Chernatony, L., Furrer, O., and Abimbola, T. (2006). Conceptualising and measuring the equity of online brands. Journal of Marketing Management, 22(7/8), 799-825.

Churchill, G.A., and Iacobucci, D. (2002). Marketing Research Methodological Foundations. 8th edition. Mason: Thomson.

Coltman, T., Devinney, T.M., Midgley, D.F., and Venaik, S. (2008). Formative versus reflective measurement models: Two applications of formative measurement. Journal of Business Research, 61(12), 1250-1262.

Cretu, A.E., and Brodie, R.J. (2007). The influence of brand image and company reputation where manufacturers market to small firms: a customer value perspective. Industry Marketing Management, 36(2). 230-40.

Cubillo, J.M., Sánchez, J., and Cerviño, J. (2006). International students' decision-making process. International Journal of Educational Management, 20(2). 101-115.

De Chernatony, L., Harris, F.J., and Christodoulides, G. (2004). Developing a brand performance measure for financial services brands. Services Industries Journal, 24(2), 15-33.

European Commission (2014). Erasmus Facts, Figures and Trends: The European Union Support for Student and Staff Exchanges and University Cooperation in 2012-2013. Luxembourg: Publications Office of the European Union.

Grewal, R., Cote, J.A., and Baumgartner, H. (2004). Multicollinearity and measurement error in structural equation models: Implications for theory testing. Marketing Science, 23(4), 519-29.

Hair, J.F., Anderson, R.E., Tatham, R.L., and Black, W.C. (2010). Multivariate Data Analysis. 7th edition. New Jersey: Prentice Hall.

Han C.M. (1989). Country image: Halo or summary construct? Journal of Marketing Research, 26(2), 222-229.

Hankinson, G. (2005). Destination brand images: a business tourism perspective. The Journal of Services Marketing, 19(1). 24-32.

Heslop, L.A., Lu, I.R.R., and Cray, D. (2008). Modeling country image effects through an international crisis. International Marketing Review, 25(4), 354-378.

Huisman, J. (2013). Higher education policy: The evolution of a journal revisited. Higher Education Policy, 26, 433-445. 
Iversen, N., and Hem, L.E. (2001). Country image in national umbrella branding effects of country associations on similarity judgments, Asia Pacific Advances in Consumer Research, 4, 140-149.

Keller, K.L. (1993). Conceptualizing, measuring, and managing customer-based brand equity. Journal of Marketing, 57(1). 1-22.

Keller, K,L. (2003). Strategic Brand Management: Building, Measuring, and Managing Brand Equity. 2nd ed. New Jersey: Prentice Hall.

Knight, J. (2011). Education hubs: A fad, a brand, an innovation? Journal of Studies in International Education, 15(3), 221-240.

Konecnik, M., and Gartner, W. (2007). Customer-based brand equity for a destination. Annals of Tourism Research, 34(2), 400-421.

Kotler, P., and Gertner, D. (2002). Country as brand, product, and beyond: A place marketing and brand management perspective. Journal of Brand Management, 9(4/5). 249-261.

Kotler, P., Haider, D.H., and Rein, I. (1993). Marketing Places: Attracting Investment, Industry and Tourism to Cities, States and Nations. New York: The Free Press.

Lin, C.-H., and Kao, D.T. (2004). The impacts of country-of-origin on brand equity. Journal of American Academy of Business, 5(Jan/Feb), 37-40.

Lin, C.-P., and Tsai, Y.H. (2008). Modeling educational quality and student loyalty: A quantitative approach based on the theory of information cascades. Quality and Quantity, 42(3), 397-415.

Lee, C-F. (2014). An investigation of factors determining the study abroad destination choice: A case study of Taiwan. Journal of Studies in International Education, 18(4), 362-381.

Lee, H-M., Lee, C-C., and Wu, C-C. (2011). Brand image strategy affects brand equity after M\&A. European Journal of Marketing, 45(7), 1091-1111.

Martin, I.M., and Eroglu, S. (1993). Measuring a multi-dimensional construct: Country image. Journal of Business Research, 28(3), 191-210.

Martinez-Lopez, F.J., Gázquez-Abad, J.C., and Sousa, C.M.P. (2013). Structural equation modelling in marketing and business research. Critical issues and practical recommendations. European Journal of Marketing, 47(1/2), 115-152.

Mehtap-Smadi, S., and Hashemipour, M. (2011). In pursuit of an international education destination: Reflections from a university in a small island state. International Journal of Educational Management, 15(5), 409-428. 
Mohd, N.Y., Nasser, M.N., and Mohamad, O. (2007). Does image of country-of-origin matter to brand equity? Journal of Product and Brand Management, 16(1). 38-48.

Morris, S.C., and Lee, C. (2011). Country of origin as a source of sustainable competitive advantage: The case for international higher education institutions in New Zealand. Journal of Strategic Marketing, 19(6), 517-529.

Mourad, M., Ennew, C., and Kortam, W. (2007). Brand equity in higher education. International Journal of Bank Marketing, 29(4), 403-420.

Nyaupane, G.P., Paris, C.M., and Teye, V. (2011). Study abroad motivations, destination selection and pre-trip attitude formation. International Journal of Tourism Research, 13(3), 205-217.

Netemeyer, R.G., Krishnan, B., Pullig, C., Wang, G., Yagci, M., Dean, D., Ricks, J., and Wirth, F. (2004). Developing and validating measures of facets of customer-based brand equity. Journal of Business Research, 57(12), 209-224.

Nguyen, T.D. (2009). Signal quality and service quality: A study of local and international MBA programs in Vietnam. Quality Assurance in Education, 17(4), 364-376.

Pappu, R., and Quester, P.G. (2010). Country equity: Conceptualization and empirical evidence. International Business Review, 19 (3), 276-291.

Pappu, R., Quester, P.G., and Cooksey, R.W. (2005). Consumer-based brand equity: Improving the measurement - Empirical evidence. Journal of Product and Brand Management, 14(3), 143-154.

Pappu, R., Quester, P.G., and Cooksey, R.W. (2006).Consumer-based brand equity and country of origin relationships. Some empirical evidence. European Journal of Marketing, 40 (5/6), 696-717.

Pappu, R., Quester, P.G., and Cooksey, R.W. (2007). Country image and consumer-based brand equity: Relationships and implications for international marketing. Journal of International Business Studies, 38, 726-745.

Perin, M.G., Sampaio, C.H., Simões, C., and de Pólvora, R.P. (2012). Modeling antecedents of student loyalty in higher education. Journal of Marketing for Higher Education, 22(1), 101-116.

Peterson, R.A., and Jolibert, A.J.P. (1995). A meta-analysis of country-of-origin effects. Journal of International Business Studies, 26(4), 83-101.

Pharr, J.M. (2005). Synthesizing country-of-origin research from the last decade: Is the concept still salient in an era of global brands? Journal of Marketing Theory and Practice, 13(4), 34-45. 
Pike, S.D. (2007). Customer-based brand equity for destinations: Practical DMO performance measures. Journal of Travel and Tourism Marketing, 22(1), 51-61.

Pike, S., and Bianchi, C. (2013). Destination brand equity for Australia: Testing a model of CBBE in short-haul and long-haul markets. Journal of Hospitality and Tourism Research, 10(10), 1-21.

Pike, S., Bianchi, C., and Kerr, G. (2010). Customer-based brand equity for Australia as a long-haul tourism destination in an emerging market. International Marketing Review, 27(4), 434-449.

Roth, K.P., and Diamantopoulos, A. (2009). Advancing the country image construct. Journal of Business Research, 62(7), 726-740.

Sanyal, S.N., and Datta, S.K. (2011). The effect of country of origin on brand equity: An empirical study on generic drugs. Journal of Product and Brand Management, 20(2), 130-140.

Sharma, A., Rao, V.R., and Popli, S. (2013). Measuring consumer-based brand equity for Indian business schools. Journal of Marketing for Higher Education, 23(2), 175-203.

Shimp, T. A., Samiee, S., and Madden, T. J. (1993). Countries and their products: A cognitive structure perspective. Journal of the Academy of Marketing Science, 21(4), 323-330.

Simon, C.J., and Sullivan, M.V. (1993). The measurement of determinants of brand equity: A financial approach. Marketing Science, 12(1), 28-52.

Simpson, K., and Tan, W. (2009). A home away from home? Chinese student evaluations of an overseas study experience. Journal of Studies in International Education, 13(1), 5-21.

Srikatanyoo, N., and Gnoth, J. (2002). Country image and international tertiary education. The Journal of Brand Management, 10(2), 139-146.

Steenkamp, J.B., and Van Trijp, H.C.M. (1991). The use of LISREL in validating marketing constructs. International Journal of Research in Marketing, 8, 283-299.

Thakor, M. V., and Katsanis, L.P. (1997). A model of brand and country effects on quality dimensions: Issues and implications. Journal of International Consumer Marketing, 9(3), 79-100.

Vázquez, R., Del Rio, A.B., and Iglesias, V. (2002). Consumer-based brand equity: Development and validation of a measurement instrument. Journal of Marketing Management, 18(1/2), 27-48. 
Wilkins, S., Balakrishnan, M.S., and Huisman, J. (2012). Student choice in higher education: Motivations for choosing to study at an international branch campus. Journal of Studies in International Education, 16(5), 413-433.

Yoo, B., and Donthu, N. (2001). Developing and validating a multidimensional consumer-based brand equity scale. Journal of Business Research, 52(1), 1-14.

Yoo, B., Donthu, N., and Lee, S., (2000). An examination of selected marketing mix elements and brand equity. Journal of the Academy of Marketing Science, 28(2), 195211.

Zeugner-Roth, K.P., Diamantopoulos, A., and Montesinos, M.A. (2008). Home country image, country brand equity and consumers product preferences: An empirical study. Management International Review, 48(5), 577-602.

Zeithaml, V.A. (1988). Consumer perceptions of price, quality, and value: A means-end model and synthesis of evidence. Journal of Marketing, 52(2), 2-22. 
Appendix 1: Likert scales from 1 (strongly disagree) to 10 (strongly agree):

Brand loyalty of the country's universities (adapted from Anselmsson et al., 2007;

Pike et al., 2010)

ULoy1 - I would choose a Spanish university again if the occasion arises

ULoy2 - I would encourage friends and family to study at a Spanish university

ULoy3 - I would recommend studying at a Spanish university if someone asked me for advice

Perceived quality of the country's universities (adapted from Pike et al., 2010; Yoo and Donthu, 2001)

UQua1 - Spanish universities have high academic standards at international level

UQua2 - Spanish universities have excellent offers at international level

UQua3 - Spanish universities have high quality at international level

Brand image of the country's universities (adapted from Anselmsson et al., 2007;

Yoo and Donthu, 2001)

UIma1 - Studying in Spanish universities improves professional and personal skills

UIma2 - Studying in Spanish universities provides professional prestige

UIma3 - Studying in Spanish universities is rewarding on a personal level

Brand awareness of the country's universities (adapted from Pike et al., 2010; Yoo and Donthu, 2001)

UAwa1- Spanish universities are recognized internationally

UAwa2- Spanish universities are famous internationally

UAwa3- Spanish universities are well known worldwide

Country image (Evaluation of Spain in the following items on the basis of the scale

developed by Cubillo et al., 2006)

CIma1- Economy

CIma2 - Science and technology

CIma3 - Socio-political environment

CIma4 - Education and culture

CIma5 - Quality of life

ULoy: loyalty toward universities; UQua: quality of universities; UIma: image of universities; UAwa: awareness of universities; CIma: country image. 


\section{Appendix 2: Correlation matrix and descriptive statistics of the research variables}

\begin{tabular}{|c|c|c|c|c|c|c|c|c|c|c|c|c|c|c|c|c|c|c|c|}
\hline & ULoy1 & ULoy2 & ULoy3 & UQua1 & UQua2 & UQua3 & UIma1 & UIma2 & UIma3 & UAwa1 & UAwa2 & UAwa3 & CIma1 & CIma2 & CIma3 & CIma4 & CIma5 & Mean & $\begin{array}{c}\text { Stand. } \\
\text { Dev }\end{array}$ \\
\hline ULoy1 & 1.00 & & & & & & & & & & & & & & & & & 7.09 & 2.31 \\
\hline ULoy2 & $0.71 * *$ & 1.00 & & & & & & & & & & & & & & & & 7.68 & 2.09 \\
\hline ULoy3 & $0.70 * *$ & $0.84^{* *}$ & 1.00 & & & & & & & & & & & & & & & 7.84 & 1.93 \\
\hline UQua1 & $0.56 * *$ & $0.50 * *$ & $0.57 * *$ & 1.00 & & & & & & & & & & & & & & 6.11 & 1.88 \\
\hline UQua2 & $0.60 * *$ & $0.53^{* *}$ & $0.60 * *$ & $0.82 * *$ & 1.00 & & & & & & & & & & & & & 6.26 & 1.80 \\
\hline UQua3 & $0.56 * *$ & $0.52 * *$ & $0.58 * *$ & $0.85^{* *}$ & $0.83^{* *}$ & 1.00 & & & & & & & & & & & & 6.25 & 1.87 \\
\hline UIma1 & $0.50 * *$ & $0.50 * *$ & $0.50 * *$ & $0.56 * *$ & $0.53 * *$ & $0.52 * *$ & 1.00 & & & & & & & & & & & 7.25 & 1.89 \\
\hline UIma2 & $0.51 * *$ & $0.53 * *$ & $0.58^{* *}$ & $0.65^{* *}$ & $0.66^{* *}$ & $0.65 * *$ & $0.67 * *$ & 1.00 & & & & & & & & & & 6.91 & 2.04 \\
\hline UIma3 & $0.51 * *$ & $0.57 * *$ & $0.59 * *$ & $0.50 * *$ & $0.51^{* *}$ & $0.47 * *$ & $0.71 * *$ & $0.63 * *$ & 1.00 & & & & & & & & & 7.98 & 1.81 \\
\hline UAwa1 & $0.38^{* *}$ & $0.40^{* *}$ & $0.50^{* *}$ & $0.68^{* *}$ & $0.71^{* *}$ & $0.68 * *$ & $0.49^{* *}$ & $0.58 * *$ & $0.42 * *$ & 1.00 & & & & & & & & 6.07 & 2.10 \\
\hline UAwa2 & $0.39 * *$ & $0.40^{* *}$ & $0.52 * *$ & $0.64 * *$ & $0.64 * *$ & $0.68 * *$ & $0.46 * *$ & $0.62 * *$ & $0.37 * *$ & $0.77^{* *}$ & 1.00 & & & & & & & 5.57 & 2.06 \\
\hline UAwa3 & $0.40 * *$ & $0.41 * *$ & $0.52 * *$ & $0.66^{* *}$ & $0.66 * *$ & $0.68 * *$ & $0.44 * *$ & $0.62 * *$ & $0.39 * *$ & $0.72 * *$ & $0.86 * *$ & 1.00 & & & & & & 5.15 & 2.07 \\
\hline CIma1 & $0.32 * *$ & $0.31^{* *}$ & $0.29 * *$ & $0.45^{* *}$ & $0.48 * *$ & $0.43^{* *}$ & $0.23^{* *}$ & $0.35^{* *}$ & $0.20^{* *}$ & $0.40^{* *}$ & $0.32 * *$ & $0.40^{* *}$ & 1.00 & & & & & 5.47 & 1.99 \\
\hline CIma2 & $0.44 * *$ & $0.44 * *$ & $0.45^{* *}$ & $0.56 * *$ & $0.62 * *$ & $0.54 * *$ & $0.37 * *$ & $0.41^{* *}$ & $0.28 * *$ & $0.50^{* *}$ & $0.44^{* *}$ & $0.49 * *$ & $0.67^{* *}$ & 1.00 & & & & 6.35 & 1.76 \\
\hline CIma3 & $0.42 * *$ & $0.43 * *$ & $0.38 * *$ & $0.50^{* *}$ & $0.50 * *$ & $0.48 * *$ & 0.30 ** & $0.36 * *$ & $0.20^{* *}$ & $0.39 * *$ & $0.42 * *$ & $0.49 * *$ & $0.56^{* *}$ & $0.62 * *$ & 1.00 & & & 6.19 & 1.70 \\
\hline CIma4 & $0.39 * *$ & $0.39 * *$ & $0.37 * *$ & $0.40^{* *}$ & $0.46^{* *}$ & $0.38 * *$ & $0.30 * *$ & $0.25^{* *}$ & $0.21^{* *}$ & $0.33^{* *}$ & $0.27 * *$ & $0.35^{* *}$ & $0.36 * *$ & $0.45 * *$ & $0.48 * *$ & 1.00 & & 7.38 & 1.66 \\
\hline CIma5 & $0.32 * *$ & $0.32 * *$ & $0.37 * *$ & $0.41 * *$ & $0.39 * *$ & $0.40^{* *}$ & $0.30 * *$ & $0.25 * *$ & $0.20 * *$ & $0.36^{* *}$ & $0.26 * *$ & $0.31 * *$ & $0.26 * *$ & $0.40 * *$ & $0.43 * *$ & $0.71^{*}$ & 1.00 & 7.66 & 1.60 \\
\hline
\end{tabular}

** $\mathrm{p}$-value $<0.01$ 